\title{
DISCUSSION
}

\section{Appreciation and Minor Clarification for Kabra (2019)}

\author{
Adam P. Novick *
}

I thank Asmita Kabra (2019, 17-18) for recognising my Masters' Thesis (Novick 2013) as contributing to ecological critiques of exclusionary conservation. I also thank Kabra $(2019,11)$ for questioning the widely presumed divide between species conservation and human rights. I am humbled if my thesis has contributed to that effort.

I wish to offer a minor clarification to Kabra's description of my thesis. Kabra in part interprets my thesis as finding that land-use policies can restrict active management essential to the survival of a species. To clarify, my thesis does not argue that land-use policies prohibit such management, but rather that they can discourage it. For example, the US Endangered Species Act (ESA) generally imposes uncompensated land-use regulation based on the presence of animal species identified ("listed") as endangered, and such regulation (whether as land-use restrictions or liability for mitigation) tends to make it self-defeating for anyone to conserve or actively maintain habitat for existing populations of declining animal species on private land (Langpap, Kerkvliet, and Shogren 2018, 77-78). For example, such regulation can impose a financial loss, by tending to decrease the market value of selectively regulated land (Novick 2013, 60-61).

At least in the USA, some conservation laws can indeed prohibit management essential to the survival of species. For example, without special authorisation for an "alternate forest practice", Oregon's Forest Practices Act (Oregon Revised Statutes 527.745) requires landowners to replant commercial tree species even if using commercial harvest to prevent

\footnotetext{
* Courtesy Faculty Research Assistant, Environmental Studies Program, University of Oregon, c/o 3715 Donald St., Eugene OR 97405 USA; anovick@uoregon.edu

Copyright (C) Novick 2019. Released under Creative Commons Attribution-NonCommercial 4.0 International licence (CC BY-NC 4.0) by the author.

Published by Indian Society for Ecological Economics (INSEE), c/o Institute of Economic Growth, University Enclave, North Campus, Delhi 110007.
}

ISSN: 2581-6152 (print); 2581-6101 (web).

DOI: https://doi.org/10.37773/ees.v2i2.79 
such species from destroying Oregon white oak savanna, a plant association that supports several at-risk species and which is imperiled in part by loss of historic burning by Native Americans (USFWS 2010). Or, for example, without special authorisation, the ESA prohibits periodic burning or other active management if it harms individuals of a species listed as endangered, even if such management is likewise essential to the species' survival.

Such laws at a minimum create bureaucratic hurdles to saving species whose survival depends on active management. However, as reflected by the respective amounts of attention in scholarship regarding the ESA, I find the disincentives from such hurdles pale in comparison to the disincentives from the risk of incurring uncompensated species-based land-use regulation. ${ }^{1}$ I can also confirm this comparison anecdotally, from personal experience with both types of disincentives, under Oregon law.

The distinction between prohibiting and discouraging species conservation is, in any case, irrelevant to Kabra's central argument, namely, that "the 'conservation versus human rights' binary tends to obliterate important debates within the ecological sciences over the theoretical foundations of exclusionary conservation" (Kabra 2019, 11; emphasis as in original). The distinction is also irrelevant to Kabra's conclusion that correspondingly broader discourse within ecology might lead to more effective conservation policies (ibid.). This is an argument and conclusion I would like to think my thesis indeed supports.

\section{REFERENCES}

Kabra, A. 2019. "Ecological Critiques of Exclusionary Conservation.” Ecology, Economy and Society-the INSEE Journal 2 (1): 9-26. https://doi.org/10.37773/ees.v2i1.51

Langpap, C., J. Kerkvliet, and J. F. Shogren. 2018. "The Economics of the U.S. Endangered Species Act: A Review of Recent Developments." Review of Environmental Economics and Policy 12 (1): 69-91. https://doi.org/10.1093/reep/rex026

Novick, A. P. 2013. "Risk to maintenance-dependent species from orthodoxy in species-based land-use regulation." Master's thesis. University of Oregon. http://hdl.handle.net/1794/13343.

US Endangered Species Act of 1973. Public law no. 93-205, 87 statute 884.

USFWS (US Fish and Wildlife Service). 2010. "Environmental Assessment for Issuance of an ESA Section 10(a)(1)(B) Permit for Incidental Take of Fender's Blue Butterfly, Taylor's Checkerspot Butterfly, Willamette Daisy, Kincaid's Lupine, Bradshaw's Lomatium, Nelson's Checkermallow, and Peacock Larkspur in Benton County." Portland, OR. Accessed June 1, 2013 at http://www.fws.gov/ecos/ajax/docs/plan documents/neas/neas 836.pdf.

${ }^{1}$ I do not recall seeing any published references to the former as disincentives, but find plenty to the latter; e.g., Langpap, Kerkvliet, and Shogren (2018, 77-78). 